\title{
Draining Lymph Node
}

National Cancer Institute

\section{Source}

National Cancer Institute. Draining Lymph Node. NCI Thesaurus. Code C150905.

The lymph node or group of lymph nodes that drain a particular anatomic site or organ. 